\title{
KAJIAN BUDAYA HUKUM PROGRESIF TERHADAP HAKIM DALAM PENEGAKAN HUKUM PADA MAFIA PERADILAN (JUDICIAL CORRUPTION) DI INDONESIA
}

\author{
Abdul Kholiq \\ Universitas Buana Perjuangan Karawang \\ Email: abdulkholiq@ubpkarawang.ac.id
}

\begin{abstract}
Abstrak
Penegakan hukum di Indonesia saat ini sangatlah jauh dari konsep negara hukum (rechtstaat), dimana idealnya hukum merupakan yang utama atau panglima, di atas segi politik dan ekonomi. Suburnya judicial corruption (pengadilan yang korup) dalam setiap proses-proses peradilan saat ini yang mengakibatkan hancurnya sistem hukum. Sistem penegakan hukum dengan "one roof system" secara konseptual akan memberikan jaminan terhadap kekuasaan kehakiman yang merdeka, lepas campur tangan kekuasaan ekstra yudisial. Maka dari itu, tindakan mafia peradilan (judicial corruption) yang melibatkan para penegak hukum di dalamnya dapat diberantas, apabila para pemegang peran komitmen serta konsisten dengan tujuan reformasi pengadilan yang telah memperkuat prinsip independensi dan imparsialitas pengadilan dalam konstitusi dan peraturan perundang-undangan. Pentingnya memahami budaya berhukum oleh seorang hakim, mengingat bahwa keyakinan hakim mempunyai peranan dominan dalam memutus suatu perkara di pengadilan, akan tetapi untuk mengetahui apakah putusan itu benar atau salah, adalah suatu hal yang sangat sulit. Maka dari pada itu, dalam pembahasan ini akan menguraikan perilaku dan budaya hukum bagi hakim dalam menegakan hukum dan keadilan dengan menggunakan nilai-nilai pada hukum progresif, sehingga menjadikan sebuah budaya hukum yang progresif pula.
\end{abstract}

Kata Kunci: Budaya Hukum, Hukum

Progresif, Penegakan Hukum, Mafia Peradilan.

Abstract
Law enforcement in Indonesia today is very far from the concept of the rule of law, where ideally the
law is the main or commander, in terms of politics and economics. The fertility of judicial corruption
in every current judicial process has resulted in the destruction of the legal system. The law
enforcement system with a "one roof system" will conceptually provide guarantees to the independent
judiciary, free from interference from extra judicial powers. Therefore, judicial corruption that
involves law enforcers in it can be eradicated, if the holders of the role of commitment and are
consistent with the objectives of court reforms that have strengthened the principle of independence
and impartiality of the courts in the constitution and legislation. The importance of understanding a
judicial culture by a judge, given that the judge's conviction has a dominant role in deciding a case
in court, but to find out whether the verdict is true or false, is a very difficult thing. So from that, in
this discussion will describe the behavior and legal culture for judges in law enforcement and justice
by using values in progressive law, thus making a progressive legal culture as well.

Keywords: Legal Culture, Progressive Law,

Law Enforcement, Judicial Corruption. 


\section{PENDAHULUAN}

Negara Kesatuan Republik Indonesia merupakan negara hukum yang berdasarkan pada Pancasila dan Undang-Undang Dasar Republik Indonesia Tahun $1945 .^{1}$ Pengaturan mengenai kedudukan Negara Indonesia sebagai negara hukum tersebut mempunyai tujuan untuk mewujudkan bangsa yang aman, tertib, sejahtera dan berkeadilan. Dalam mewujudkan tujuan dari Negara Indonesia maka harus diperlukan adanya kesadaran dari semua komponen masyarakat dan pemerintah serta penegak hukum. Abdul Hakim Garuda Nusantara mengatakan bahwa bagaimanapun hukum di Indonesia harus mengacu pada cita-cita masyarakat bangsa yakni tegaknya negara hukum yang demokratis dan berkeadilan sosial. Pembangunan hukum harus ditujukan untuk mengakhiri tatanan sosial yang tidak adil dan menindas hak-hak asasi manusia, sehingga politik hukum harus berorientasi pada cita-cita negara hukum yang didasarkan atas prinsipprinsip demokrasi dan berkeadilan sosial dalam suatu masyarakat bangsa

\footnotetext{
${ }^{1}$ Pasal 1 ayat (3) Undang-Undang Dasar Negara Republik Indonesia Tahun 1945
}

Indonesia yang bersatu sebagaimana tertuang di dalam pembukaan UndangUndang Dasar 1945. ${ }^{2}$

Bangsa Indonesia pada masa kini berkembang dan bergerak sangat dinamis, hal ini bisa karena faktor transformasi dan globalisasi dunia yang menuntut bangsa Indonesia ikut andil dalam keberlangsungan kehidupan bernegara. Lebih dari dasawarsa reformasi berjalan di Indonesia, cita-cita agar terwujudnya supremasi hukum sebagai salah satu tujuan reformasi tampaknya masih jauh dari harapan. Meski tampak muncul sinyal perbaikan dalam menghadapi masalah-masalah yang terjadi di Indonesia, namun masalah mendasar yaitu perilaku korup dan minimnya budaya taat hukum, seolah tak pernah beranjak membaik sebagaimana yang telah disuarakan baik pemerintah maupun masyarakat Indonesia. $^{3}$

$$
\text { Peranan hukum dalam }
$$
pembangunan adalah untuk menjamin

2 Abdul Hakim Garuda Nusantara, Politik Hukum Indonesia, Jakarta: Yayasan LBH Indonesia, 1988, hlm. 20

3 Wicipto Setiadi, Arti Penting Lembagalembaga Hukum di Indonesia dalam Merespon Perubahan Sosial, Dalam Jurnal Komisi Yudisial "Dialektika Pembaharuan Sistem Hukum Indonesia, Jakarta, 2012, hlm. 46 
perubahan itu dengan cara yang teratur.

Perubahan yang teratur demikian dapat dibantu oleh peraturan perundangundangan atau keputusan pengadilan atau kombinasi kedua-duanya. Perubahan yang teratur melalui prosedur hukum, baik ia berwujud peraturan perundang-undangan atau keputusan badan-badan peradilan lebih baik daripada perubahan yang tidak teratur dengan menggunakan kekarasan semata-mata. ${ }^{4}$

Penegakan hukum di Indonesia saat ini sangatlah jauh dari konsep negara hukum (rechtstaat) dimana idealnya hukum merupakan yang utama atau panglima, di atas segi politik dan ekonomi. Suburnya judicial corruption (pengadilan yang korup) dalam setiap proses-proses peradilan saat ini yang mengakibatkan hancurnya sistem hukum. Lembaga peradilan menjadi tercemar karena keacuhan aparat penegak hukum akan penegakan hukum yang efektif, serta rendahnya kualitas sumber daya manusia baik secara inteletualis maupun spiritualis, adanya

4 Mochtar Kusumatmadja, Pembangunan Hukum Dalam Kerangka Pembangunan Nasional, Cetakan Kedua, Fakultas Hukum Universitas Padjajaran dan Bina Cipta, Bandung, 1986, hlm. 3 birokrasi peradilan yang berjenjang, pengawasan internal yang sangat lemah dan rendahnya integritas pimpinan atau struktur dari aparat penegak hukum itu sendiri.

Adanya permasalahan yang ironis di bangsa Indonesia yang berkaitan dengan judicial corruption yang terus menggerogoti indepedensi atau kedigdayaan lembaga pengadilan (pengadilan tipikor), sebagaimana menjadi benteng terakhir pemberantasan korupsi. Permasalahan tersebut tidak lain juga menyangkut adanya praktik jual beli hukum (putusan perkara) yang melibatkan hakim serta jamaknya vonis bebas bagi koruptor di beberapa daerah tertentu. Bukti adanya praktik judicial corruption dengan tertangkapnya dua hakim ad hoc Pengadilan Tindak Pidana Korupsi (Tipikor) yaitu Kartini Juliana Magdalena Marpaung yang bertugas di PN Semarang dan Heru Kisbandono yang bertugas di PN Pontianak. Keduanya ditangkap oleh KPK saat menerima uang terkait perkara yang ditangani dengan nilai suap Rp.150.000.000 (seratus lima puluh juta rupiah), dan keduanya telah divonis hukuman atas tindakan penyuapan 
(korupsi) dengan penjara 8 tahun denda 500 juta rupiah dan pidana 8 tahun denda 200 juta rupiah. ${ }^{5}$ Selain itu juga ada tindakan hakim Setyabudi Tejocahyono yang bertugas di PN Bandung, terbukti menerima suap dalam penanganan perkara Bansos Kota Bandung 2009-2010 yang merugikan keuangan negara senilai Rp 66 Miliar. Akibat perbuatannya tersebut maka dijatuhi hukuman pidana penjara selama 12 tahun denda $\mathrm{Rp} 200$ juta dan subsider kurungan 3 bulan penjara. ${ }^{6}$

Kasus lain yang berubungan dengan tindakan judicial corruption di Indonesia yang menghenyakkan masyarakat Indonesia dengan tertangkapnya Akil Mochtar seorang hakim konstitusi pada tanggal 2 Oktober 2013 dirumahnya, ia diduga menerima uang suap sebesar Rp 2,7 Miliar yang ditemukan oleh petugas KPK dirumahnya tersebut (Tempo.com). Dari tindakannya tersebut saat ini tersangka masih dalam

5 http://www.kpk.go.id/id/berita/siaranpers/1556-kasus-suap-hakim-tipikorsemarang-kpk-tahan-hakim-p (accesed: 2612-2013, 14:52)

6

http://www.merdeka.com/peristiwa/teri ma-suap-hakim-setyabudi-divonis-12tahun-penjara.html (accesed: 26-122013, 14:58) pemeriksaan yang dilakukan oleh KPK Hal ini sangat ironis sekali meskipun sebenarnya tindakan-tindakan korupsi di Indonesia sudah mewabah di seluruh lapisan eksekutif, legislatif maupun yudikatif. Oleh karena itu akibat dari perbuatan korupsi itu sendiri merupakan tamparan yang keras bagi Negara Indonesia yang menyebut dirinya sebagai negara demokrasi dan menempatkan hukum dalam posisi tertinggi.

Melihat dari beberapa kasus di atas menunjukkan budaya koruptif yang membelenggu semua sendi kehidupan berbangsa dan bernegara di Indonesia, hingga merasuk ke dalam dunia (lembaga) peradilan khususnya dalam penegakan kasus tindak pidana korupsi. Sehingga dari upaya penegakan hingga pemberantasan korupsi seakan-akan tidak ada ujungnya dan kepercayaan masyarakat pada lembaga peradilan sudah sangat rendah dan hampir mencapai titik nadir. ${ }^{7}$ Penegak hukum didengungkan sebagai profesi luhur (honorable profession), namun disisi

\footnotetext{
${ }^{7}$ Sinintha Y. Sibarani, Budaya Hukum Progresif Hakim Ad Hoc dalam Penegakan Hukum Tipikor, dalam Proceeding Konsorsium Hukum Progresif 2013, di Hotel Patrajasa Semarang, hal 404
} 
lain diperburuk citranya dengan perilaku-perilaku koruptif dari penyandang profesi tersebut.

Meskipun terlihat banyaknya kasus-kasus korupsi khususnya dalam lingkungan peradilan (judicial corruption), namun terdapat secercah harapan muncul ketika terlihat besarnya tekad pemerintah dalam memberantas korupsi yakni dengan membentuk lembaga-lembaga ad hoc misalnya Komisi Pemberantasan Korupsi dan Pengadilan Tindak Pidana Korupsi. ${ }^{8}$ Adanya lembaga-lembaga tersebut diharapkan mampu memberantas kejahatan korupsi yang sudah mengakar hingga merugikan keuangan negara yang banyak. Konsekuensi dari terbentuknya Pengadilan Tipikor yang di dalamnya terdapat hakim adhoc maka kepercayaan yang diberikan dari masyarakat dalam memberantas korupsi haruslah sebanding dengan harapan masyarakat itu sendiri.

Hukum dan lembaga penegak hukum merupakan lembaga yang penting, namun kelihatannya kecil jika dibandingkan dengan bentuk-bentuk

\footnotetext{
${ }^{8}$ Lihat Undang - undang Nomor 30 Tahun 2002 tentang KPK dan Undang - Undang Nomor 46 Tahun 2009 Tentang Pengadilan Tindak Pidana Korupsi.
}

atau mode-mode yang mengatur perilaku. Dapat dilihat dalam pelaksanaannya di pengadilan, bahwa hakim melakukan penyelewengan berupa penyelesaian perkara yang tidak adil dan menghasilkan putusan-putusan yang dapat diintervensi, karena adanya faktor-faktor penyebab antara lain seperti gaji hakim yang dipandang kecil yang tidak sebanding dengan resiko dan tanggungjawabnya, tekanan dari kekuasaan yang lebih tinggi, adanya intervensi politik dan ekonomi dan juga berhubungan dengan integritas dan moralitas hakim itu sendiri. Oleh karena itu perlunya pemahaman dan pengkajian terhadap budaya hukum bagi hakim di dalam melaksanakan tugas dan fungsinya untuk penegakan hukum dalam tindak pidana korupsi.

\section{PERMASALAHAN}

Berdasarkan hal-hal yang telah diungkapkan dalam latar belakang, maka dibuat rumusan masalah sebagai berikut :

1. Bagaimana penegakan hukum terhadap mafia peradilan (judicial corruption) di Indonesia selama ini? 
2. Mengapa budaya hukum progresif diperlukan bagi hakim dalam penegakan hukum terhadap mafia peradilan (judicial corruption)?

\section{METODE PENELITIAN}

Metode pendekatan yang digunakan dalam penulisan ini adalah dengan yuridis-normatif. Pendekatan tersebut dimaksudkan jenis penelitian dogmantis dan bentuk penelitian perskriptif dalam hubungan pada hukum-hukum. Selanutnya spesifikasi penelitian ini yaitu deskriptif-analitis, yakni dengan memberikan gambaran terhadap masalah yang diangkat dan memberikan analisis dari masalah sehingga mampu memberikan jawaban atas permasalahan tersebut.

Metode pengumpulan data dalam penelitian ini adalah menggunakan metode kepustakaan (library research) dengan maksud menguji bahan-bahan dokumen dan bahan pustaka yang digunakan dalam penelitian ini. Data dianalisis secara kualitatif-normatif, yaitu melakukan penelitian dengan jalan menafsirkan dan membangun pernyataan yang terdapat dalam dokumen peraturan perundangundangan. Metode analisis kualitatif, dibangun berdasarkan data dan substansinya yang berasalah atau bersumber dari berbagai literatur seperti buku, jurnal, dan karya ilmiah, peraturan perundang-undangan, dan data primer yang diperoleh dari wawancara, pengamatan dan studi lapangan. Selanjutnya dari bahan-bahan tersebut akan dianalisis dengan normatifnya sebagaimana diatur dalam undang-undang, teori dan pendapatpendapat para ahli hukum yang berhubungan dengan kajian budaya hukum progresif bagi hakim dalam penegakan hukum terhadap mafia peradilan di Indonesia.

\section{PEMBAHASAN}

\section{Penegakan Hukum Terhadap Mafia Peradilan (Judicial Corruption) Di Indonesia}

Hukum dan masyarakat berhubungan secara timbal balik, karena hukum sebagai sarana pengantar masyarakat bekerja di dalam kehidupan bermasyarakat. Hubungan tersebut dapat bersifat simbiosis mutualistis yaitu mendukung tumbuh dan tegaknya hukum, maupun sebaliknya bersifat 
parasitis yaitu menghambat tumbuh kembang dan tegaknya hukum. ${ }^{9}$ Dalam mendukung bekerjanya hukum dengan baik dalam masyarakat maka diperlukan pemahaman dan kesadaran dari seluruh komponen-komponen seperti pemerintah (pembuat undang-undang), aparat penegak hukum dan masyarakat sebagai pelaku dari hukum itu sendiri. Karena pentingnya kesadaran hukum ini berarti kesadaran untuk bertindak sesuai dengan ketentuan hukum. Adanya kesadaran hukum yang tumbuh di masyarakat merupakan semacam jembatan yang meghubungkan antara peraturan-peraturan hukum dengan tingkah laku hukum dari anggota masyarakat.

Penegakan hukum selama ini di Indonesia masih kurang memberikan kepuasan bagi para pihak-pihak pencari keadilan. Upaya dalam penegakan hukum dirasa sangat urgen dalam menata seluruh ketertiban masyarakat. Sehingga diharapkan masyarakat dapat berbudaya hukum. Penegakan hukum bukanlah suatu hal yang berdiri sendiri,

9 Nur Rohim Yunus, Menciptakan Budaya Hukum Masyarakat Indonesia dalam Dimensi Hukum Progresif, dalam Proceeding Konsorsium Hukum Progresif 2013, di Hotel Patrajasa Semarang, hal 181 melainkan saling terkait dengan masalah-masalah sosial masyarakat lainnya. Artinya hukum bukan hanya sebagai sistem nilai, tetapi juga sebagai sub sistem dari sistem sosial yang lebih besar yaitu masyarakat dimana hukum diberlakukan. Maka tak heran jika ada adagium yang familiar menyatakan :" meskipun dunia akan runtuh hukum harus ditegakkan (fiat justitia et pereat mundus)". ${ }^{10}$

Berkaitan dalam penegakan hukum pada maraknya mafia peradilan (judicial corruption) di Indonesia, bahwa penegakan hukum pidana terdistorsi rasionalitas transaksi ekonomi sehingga proses peradilan pidana tidak lebih dari lembaga yang mencari "pembenaran (justification)", yang seharusnya lembaga pengadilan itu mencari "kebenaran (truth)" dan "keadilan (justice)"." Praktik mafia peradilan (judicial corruption) semakin kreatif dalam membuat pembenaran pada setiap proses hukum yaitu dengan membentuk tim loby sebagai bagian strategi pembelaan perkara tim pengacara untuk merekayasa proses hukum. Pembelaan perkara pidana tidak

\footnotetext{
${ }^{10}$ Ibid, Nur Rohim Yunus, hal 182

${ }^{11}$ Op. Cit. J. Pajar Widodo, 2012, hal 109
} 
lagi dibangun atas dasar sebuah argumentasi hukum yang logis, melainkan berdasarkan kekuatan lobyloby dan pendekatan ke berbagai pihak yaitu penyidik, penuntut umum dan hakim untuk dapat memenangkan perkara yang telah ditanganinya. Bentuk loby yang biasa dilakukan oleh pihak tersebut dapat berupa meringankan hukuman atau membebaskan terdakwa dari hukuman pidana.

Proses peradilan yang dilaksanakan dalam lembaga pengadilan untuk menyelesaikan perkara-perkara hukum saat ini menunjukkan kaburnya orientasi para penegak hukum antara usaha menegakkan hukum dan menegakkan keadilan. Tujuan utama dalam berperkara bukan untuk menegakkan hukum dan keadilan, tetapi untuk memenangkan perkara. Adanya suatu pergeseran orientasi para aparat penegak hukum tersebut lebih menekankan rasionalitas-pragmatis dengan mendistorsi nilai etis dari moral penegakan hukum dan keadilan. Kemudian melakukan pembelokan yang berkaitan dengan problem konseptual yuridis. Paradigma positivisme hukum yang mewarnai terbentuknya hukum modern yaitu mengedepankan fungsi peraturan perundang-undangan, cenderung terikat pada formalisme dan prosedural peraturan perundangundangan dan kurang menggali nilainilai substansial dari hukum, sehingga tindakan tersebut akhir-akhir ini menimbulkan kritik-kritik yang tajam. Kritik terhadap karakter hukum modern yaitu bagaimana keluar dari formalisme yang membabi-buta dan bagaimana mendamaikan prinsip legalitas hukum dengan moralitas. ${ }^{12}$

Lembaga peradilan seharusnya menjalankan fungsi kemasyarakatan, dengan menggerakkan pengadilan untuk menyelesaikan masalah hukum dalam masyarakat tidak sebatas menerapkan peraturan perundang-undangan yang menekankan kepastian hukum (undangundang). Konsep hukum sebagai teks undang-undang dala penerapannya bertolak dari silogisme metodologis, terstruktur dalam silogisme deduktiflogis sehingga subjektivitas nilai etis moral terperangkap di dalam logika

12 C. Maya Indah S, Refleksi sosial atas Kelemahan Hukum Modern : Suatu Diseminasi Hukum Tradisional dalam Citra Hukum Indonesia, Jurnal Masalah-Masalah Hukum, FH Universitas Diponegoro, Semarang, Vol 103 No. 37 , Tahun 2008, hal 164 
deduktif-logis. Oleh karena itu, hakim dalam menjatuhkan suatu putusan hukum tidak lebih hanya sebagai konklusi dari deduksi teks undangundang tersebut terhadap peristiwa konkritnya. Dari hal yang demikian maka mengenai pertimbangan adil atau tidak adil menjadi keniscayaan (nisbi), karena argumentasi hukum yang diberikan oleh hakim berakhir dalam sebuah konklusi logika deduksi yang lebih menekankan adanya kepastian hukum dan mengabaikan nilai-nilai moral keadilan yang ada di dalamnya.

Dengan berdasarkan penjelasan di atas mengenai argumentasi yang berkaitan hakim dalam mengambil putusan hukum dari perkara yang telah dihadapainya, maka sangat dimungkinkan terjadinya mafia peradilan (judicial corruption) bahkan mampu tumbuh dengan subur di dalam praktiknya. Pembuatan argumentasi hukum yang dibangun hakim, tidak nampak cacat hukum serta dapat dipertanggungjawabkan lepas dari produk putusan kolutif. Selama ini koreksi putusan hanya terjadi secara internal dalam struktur vertikal seperti upaya hukum banding oleh Pengadilan Tinggi dan Kasasi serta Peninjauan
Kembali (PK) oleh Mahkamah Agung. Putusan hukum yang kolutif ini penuh dengan rekayasa dengan demikian tidak terjangkau dari koreksi atau eksaminasi eksternal pengadilan, khususnya masyarakat yang menjadi tujuan dari produk putusan pengadilan.

Semangat untuk memberantas praktik korupsi di pengadilan hanya menyalahkan sistem yang ada dan kurang berorientasi pada pengawasan kinerja profesionalitas penegak hukum yang menyalahgunakan kekuasaan (abuse of power) yang disamarkan dalam legalitas kewenangan penegak hukum. ${ }^{13}$ Persoalan konseptual yang menyangkut penegakan hukum pidana, bersumber dari sistem penegakan hukum yang dibangun berdasarkan desain konstitusional. Dasar konstitusional yang mengatur mengenai kekuasaan kehakiman dilakukan oleh sebuah Mahkamah Agung dan badan peradilan yang berada dibawahnya dalam lingkungan peradilan umum, lingkungan peradilan agama, lingkungan peradilan militer dan

\footnotetext{
13 Jawade Hafidz, Sistem Pertanggungjawaban Perkara Korupsi Dalam Percepatan Penyelamatan Keuangan Negara, Jurnal Dinamika Hukum, Vol 11 Edisi Khusus, FH Unsoed Purwokerto, Februari 2011, hal 116
} 
lingkungan peradilan tata usaha negara, dan oleh sebuah Mahkamah Konstitusi. ${ }^{14}$ Setelah itu diikuti terbitnya Undang - Undang Nomor 48 Tahun 2009 Tentang Kekuasaan Kehakiman sebagai peraturan pelaksana dan penjelasan yang diamanatkan oleh Undang-Undang Dasar 1945 tersebut. Adanya lembaga Komisi Yudisial merupakan lembaga pengawas hakim secara eksternal sebagai pendukung tugas-tugas kekuasaan kehakiman. Sehingga pada dasarnya didesain sebagai lembaga yang melaksanakan kekuasaan kehakiman yaitu sebagai supporting element berpasangan dengan Mahkamah Agung dan Mahkamah Konstitusi untuk memperkuat prinsip kekuasaan kehakiman yang independen dan imparsial, guna menegakkan hukum dan keadilan.

Fenomena terjadinya mafia peradilan (judicial corruption) misal suap-menyuap atau pemberian hadiah (gratifikasi) dilingkungan peradilan pada dasarnya merupakan bentuk pertukaran kekuasaan yaitu antara "kekuasaan hukum" dan "kekuasaan materi/uang" yang dipegang oleh

14 Pasal 24 Ayat (2) Undang - Undang Dasar 1945 pencari keadilan (tersangka/terdakwa). Dengan terungkapnya beberapa kasus suap-menyuap seperti yang digambarkan di atas, khususnya dalam lingkungan lembaga peradilan yang melibatkan oknum aparat penegak hukum merupakan bentuk judicial corruption menjadi titik balik dan anomali reformasi peradilan secara substansial telah berhasil menempatkan lembaga pengadilan sebagai pelaksana kekuasaan kehakiman yang independen yaitu dengan menggunakan desain sistem penegakan hukum yang bertumpu pada "One roof system (sistem satu atap/sistem atap tunggal), dengan puncak kekuasaan kehakiman berada di Mahkamah Agung. ${ }^{15}$

Sistem penegakan hukum hukum dengan "one roof system" secara konseptual akan memberikan jaminan terhadap kekuasaan kehakiman yang merdeka, lepas campur tangan kekuasaan ekstra yudisial. Maka dari itu, tindakan mafia peradilan (judicial corruption) yang melibatkan para penegak hukum di dalamnya dapat diberantas, apabila para pemegang peran komitmen serta konsisten dengan

\footnotetext{
${ }^{15}$ Op. Cit. J. Pajar Widodo, 2012, hal 113
} 
tujuan reformasi pengadilan yang telah memperkuat prinsip indepedensi dan imparsialitas pengadilan dalam konstitusi dan peraturan perundangundangan. Adanya reformasi sistem penegakan hukum harus bersifat integral yakni dimulai dengan melakukan reformulasi dan rekonseptualisasi kekuasaan kehakiman.

Dengan menata ulang "kekuasaan kehakiman" dalam lembaga peradilan menjadi penting karena pemberian kekuasaan kehakiman yang hanya tertuju kepada pengadilan menjadi titik lemah dalam sistem peradilan itu sendiri. Sebagaimana ditegaskan dalam Pasal 1 Ayat (1) Undang-Undang Nomor 48 Tahun 2009 Tentang Kekuasaan Kehakiman, menjelaskan bahwa sebagai kekuasaan negara yang merdeka untuk menyelenggarakan peradilan guna menegakkan hukum dan keadilan. Hal tersebut sangat menentukan kualitas, kredibilitas dan integritas keseluruhan proses peradilan. Sehingga segala praktik-praktik mafia peradilan yang menggerogoti indepedensi peradilan akan terminimalisir bahkan tidak terjadi karena komitmen dari para aparat penegak hukum.
2. Budaya Hukum Progresif Diperlukan Bagi Hakim Dalam Penegakan Hukum Terhadap Mafia Peradilan (Judicial Corruption)

Dalam konteks budaya, pemahaman budaya hukum dimaksud dapat diperjelas menjadi seperangkat nilai, gagasan, norma yang menjadi pedoman berfikir, berucap, berperilaku dan bertindak sesuai dengan yang diharapkan oleh sebagian besar warga masyarakat. Hal ini berarti budaya hukum masyarakat merupakan seperangkat nilai, gagasan, norma yang terbangun dari budhi dan daya warga masyarakat dan telah terinternalisasi ke dalam alam kesadaran (mindset) secara turun temurun dan berfungsi sebagai pedoman yang meghubungkan antara peraturan-peraturan hukum pada tataran teori di satu pihak dan perilaku atau tindakan nyata pada tataran praksis yang diharapkan oleh masyarakat.

Jika dalam kehidupan bermasyarakat terjadi suatu kegagalan untuk mewujudkan salah satu nilai-nilai tersebut dapat menimbulkan hasil-hasil yang tidak sesuai dengan apa yang diharapkan dari isi peraturan (hukum) itu. Namun demikian, sebaik apapun 
hukum yang dibuat, pada akgirnya sangat ditentukan oleh budaya hukum masyarakat yang bersangkutan. Berbicara mengenia budaya hukum adalah berbicara mengenai bagaimana sikap-sikap, pandangan-pandangan serta nilai-nilai yang dimiliki oleh masyarakat. Semua komponen budaya hukum itulah yang sangat menentukan berhasil tidaknya kebijaksanaan yang telah dituangkan dalam bentuk hukum. ${ }^{16}$

Kesadaran hukum pada dasarnya merupakan kontrol agar hukum dibuat dan dilaksanakan sebaik mungkin. Maka perlu adanya usaha-usaha ke arah pembinaan kesadaran hukum yang berorientasi kepada penanaman, pemasyarakatan dan pelembagaan nilainilai yang mendasari peraturanperaturan tersebut. Kesadaran memerlukan adanya hukum sebagai sarana yang disengaja guna mencapai tujuan-tujuan yang dikehendaki, yang tentunya merupakan keinginan masyarakat bersama. Sehingga dapat menjadi sarana penunjang untuk merealisasikan kebijakan-kebijakan

\footnotetext{
${ }^{16}$ Esmi Warassih P, Pranata Hukum : Sebuah Telaah Sosiologis, Semarang: Badan Penerbit Universitas Diponegoro, 2011, hal 83
}

negara, baik dalam bidang ekonomi, politik, sosial budaya dan hukum sesuai dengan skala prioritas yang telah ditentukan. ${ }^{17}$

Pemahaman mengenai kesadaran hukum terkait sangat erat dengan budaya hukum masyarakat, dengan kata lain bahwa tingkat kesadaran hukum masyarakat tinggi atau rendah dapat dilihat dari budaya hukumnya. Jika budaya hukum yang berkembang di suatu masyarakat tertentu cenderung positif dan proaktif terhadap cita hukumnya tentu masyarakatnya memiliki tingkat kesadaran hukum yang tinggi. Sebaliknya jika suatu masyarakat tidak memiliki budaya hukum yang baik (positif) dan cenderung acuh tak acuh mengenai budaya hukum yang berkembang, maka masyarakat tersebut tingkat kesadaran hukumnya rendah dan lemah sehingga rentan sekali terjadi penyelewengan kewenangan, kekuasaan oleh pemangku hukum serta menimbulkan rasa ketidakadilan dan kekacauan di masyarakat tersebut.

Dalam budaya hukum masyarakat dapat pula dilihat apakah masyarakat dalam kesadaran hukumnya sungguhsungguh telah menjunjung tinggi hukum

${ }^{17}$ Op. Cit, Nur Rohim Yunus, 2013, hal 183 
sebagai aturan main dalam hidup bersama dan sebagai dasar setiap penyelesaian masalah yang timbul dari resiko hidup bersama. Menurut Satjipto Rahardjo $^{18}$ menyimpulkan secara eksplisit, bahwa adanya perasaan tidak bersalah sekalipun putusan pengadilan telah menyatakan yang bersangkutan bersalah, merupakan preseden buruk bagi tegaknya budaya hukum di negeri ini. Maksud dalam penyatakan tersebut mengandung pesan yang dalam mengenai perlunya mentradisikan budaya hukum di negeri ini, karena tanpa tertanamnya budaya hukum mustahil akan dapat ditegakkan hukum yang berkeadilan. Oleh karenanya, sekalipun masyarakat sadar terhadap hukum yang berlaku di negaranya, belum tentu masyarakat tersebut patuh pada hukum yang berkembang. Kepatuhan terhadap hukum merupakan hal yang substansial dalam membangun budaya hukum di negeri ini.

Menurut Lawrence M. Friedman ${ }^{19}$ menjelaskan yang berkaitan dengan budaya hukum yang diartikan sebagai alat untuk mempertegas fakta bahwa

18 Satjipto Rahardjo, Sisi Lain dari Hukum DI Indonesia, Jakarta: Penerbit Kompas, 2003, hal55.

${ }^{19}$ Op, Cit, Lawrence M. Friedman, 2011, hal 62 hukum paling baik dipahami dan digambarkan sebagai sebuah sistem yang terdiri dari struktur hukum (legal structure), substansi hukum (legal substance) dan budaya hukum (legal culture). dalam hal ini, hukum diartikan sebagai putusan hakim yang dipahami sebagai sebuah hasil dari proses menyatunya antara unsur kekuatankekuatan sosial dan kekuatan-kekuatan hukum sebagai "masukan" (input), yang kemudian menghasilkan hukum. Produk hukum yang disebut terakhir merupakan saluran dari kekuatan-kekuatan sosial dan kekuatan-kekuatan hukum yang akan memiliki dampak ketertiban hukum masyarakat sebagai "keluaran" (output).

Pentingnya memahami budaya berhukum oleh seorang hakim, mengingat bahwa keyakinan hakim mempunyai peranan dominan dalam memutus suatu perkara di pengadilan. Akan tetapi, untuk mengetahui apakah putusan itu benar atau salah, adalah suatu hal yang sangat sulit. Maka daripada itu, dalam pembahasan ini akan menguraikan perilaku dan budaya hukum bagi hakim dalam menegakkan hukum dan keadilan dengan menggunakan nilai-nilai pada hukum 
progresif, sehingga menjadikan sebuah budaya hukum yang progresif pula. Karena maraknya kasus-kasus korupsi seperti mafia peradilan (judicial corruption) sebagaimana telah diuraikan di atas. Serta memperhatikan kondisi lembaga peradilan yang sudah menciderai indepedensi dan kemandiriannya dengan terjadinya praktik-praktik mafia peradilan (judicial corruption), maka membuat profesionalitas para aparat penegak hukum di negeri ini sudah berada di titik nadir. Masyarakat pun juga telah merasakan pesimistis untuk mempercayakan bahwa setiap perkara yang diselesaikan lewat jalur peradilan akan memberikan keadilan sebagaimana diharapkan oleh para pencari keadilan itu sendiri. Dengan banyaknya terungkap kasus-kasus yang melibatkan hakim dalam praktik judicial corruption seperti jual beli perkara yang sudah dianggap tidak aneh sehingga wajar terjadi dalam praktiknya khususnya dalam mengintervensi putusan hukum yang akan dijatuhkan.

Berdasarkan pada uraian di atas dalam kondisi hukum dan penegakannya tersebut, oleh Satjipto Rahardjo menawarkan gagasan dan pemikiran hukum dan penegakan hukum yang progresif sebagai pertimbangan yang relevan menjadi model perilaku para hakim (maupun hakim ad hoc) sehingga terbangun menjadi suatu budaya hukum progresif. Maksud dari hukum progresif itu sendiri adalah mengubah secara cepat, melakukan pembalikan secara mendasar dalam teori dan praksis hukum, serta melakukan berbagai terobosan. Pembebasan tersebut didasarkan pada prinsip bahwa hukum adalah untuk manusia dan bukan sebaliknya serta hukum itu tidak ada untuk dirinya sendiri, melainkan untuk sesuatu yang lebih luas yaitu untuk harga diri manusia, kebahagiaan, kesejahteraan dan kemulaiaan manusia. ${ }^{20}$

Pemberdayaan hukum progresif yang bertumpu pada kualitas aparat penegak hukum terutama hakim dapat dijadikan alternatif untuk mengatasi masalah ketidakadilan. Menurut Kimball, yang menyatakan bahwa memisahkan antara hukum dan keadilan merupakan korupsi moral, sedangkan Hakim Agung Artidjo Alkotsar, menyatakan bahwa hakim yang berfikir

${ }^{20}$ Op. Cit. Sinintha Y. Sibarani, 2013, hal 410 
progresif berarti menggunakan hukum terbaik dalam keadaan buruk. ${ }^{21}$ Para hakim perlu mendapat pembelajaran agar berani membaca teks dengan bebas dan progresif yaitu menempatkan pada konteks sosial dan tujuan sosial masa kini. Para hakim tidak usah ragu dalam melakukan pembebasan asal bisa memberikan argumentasi yang merupakan hal penting dan bisa diajukan dengan keberanian ke luar dari paradigma liberal dan menempatkan fungsi hukum untuk melayani, menjamin dan menjaga kebutuhan Indonesia. $^{22}$

Dengan adanya budaya baru pada sistem penegakan hukum yang berangkat dari paradigma (sudut pandang) bahwa penegakan hukum untuk melayani dan menjaga kepentingan rakyat, bukan menekankan kepada "independensi sistem". Indepedensi komponen hanya menjadi alat, bukan tujuan yang utama. Artinya tujuan utama tersebut adalah tujuan sosial untuk memberikan sebesar-

21 Tim LBH Surabaya, (Masih) Berkuasanya Kekuasaan Kegelapan: Potret Penegakan Hukum dan HAM, Malang: In-Trans Publishing, 2009, hal 14-15

${ }^{22}$ Satjipto Rahardjo, Hukum Progresif Sebuah Sintesa Hukum Indonesia, Yogyakarta: Genta Publishing, 2009, hal 144 besarnya keadilan kepada masyarakat, namun tanpa sama sekali mengorbankan keadilan individual (pelaku). Adanya perubahan pemikiran yang demikian tadi niscaya akan berdampak pada penataan sistem penegakan hukum, bahkan sampai kepada perubahan budaya hukum hukum (pen). Sebagai penentu keadilan atas perkara yang ditanganinya bagi lembaga peradilan dengan mengilhami budaya hukum progresif tersebut maka akan meningkatkan kewibawaan putusan pengadilan sebagai output atau produk akhir dari suatu lembaga kekuasaan kehakiman (pengadilan). Serta mampu memberikan dan memulihkan rasa kepercayaan dari masyarakat atas segala keputusan hukum yang dikeluarkannya, akibat terjadinya tindakan-tindakan mafia peradilan (judicial corruption) yang dilakukan oleh oknum-oknum aparat penegak hukum di lingkungannya. Hal ini semua membutuhkan keterlibatan dan peran serta yang maksimal oleh seluruh elemen dan komponen penegak hukum baik secara vertikal maupun horizontal dan juga masyarakat, dapat dilakukan mulai dari mempersiapkan sumber daya manusia bagi seorang hakim yang 
intelektual, mempunyai integritas tinggi dan berani melakukan terobosan hukum yang berdampak positif yaitu keadilan bagi pencari keadilan itu sendiri.

\section{KESIMPULAN}

Berdasarkan hasil penelitian dan pembahasan maka dapat disimpulkan penelitian ini sebagai berikut:

1. Penegakan hukum terhadap mafia peradilan (judicial corruption) yang terjadi di Indonesia masih kurang memuaskan dan bahkan masyarakat pun juga telah merasakan pesimistis untuk mempercayakan bahwa setiap perkara yang diselesaikan lewat jalur peradilan akan memberikan keadilan sebagaimana diharapkan oleh para pencari keadilan itu sendiri. Dengan banyaknya terungkap kasus-kasus yang melibatkan hakim dalam praktik judicial corruption seperti jual beli perkara yang sudah dianggap tidak aneh sehingga wajar terjadi dalam praktiknya khususnya dalam mengintervensi putusan hukum yang akan dijatuhkan. Namun dengan demikian, kiranya dengan melakukan reformasi dan rekonstruksi lembaga peradilan dengan menggunakan sistem satu atap (atap tunggal) "one roof system" yang dipegang atau tumpuan kepada Mahkamah Agung, sehingga diharapkan mampu meminimalisir bahkan memberantaskan praktik-praktik judicial corruption di Indonesia.

2. Budaya hukum progresif sangat diperlukan oleh para hakim (termasuk hakim adhoc) dalam menyelesaikan perkara-perkara hukum dan untuk menegakkan hukum juga memberikan keadilan kepada masyarakat. Karena keyakinan hakim mempunyai peranan dominan dalam memutus suatu perkara di pengadilan. Adanya budaya hukum yang sifatnya progresif ini, berparadigma bahwa penegakan hukum untuk melayani dan menjaga kepentingan rakyat, bukan hanya menekankan pada indepedensi sistem dari kekuasaan kehakiman. Budaya hukum progresif yang dilakukan oleh lembaga peradilan (hakim) dalam menyelesaikan masalah akan berorientasi pada meningkatnya kewibawaan putusan pengadilan 
yang dikeluarkan sebagai produk hukum dari lembaga peradilan, sehingga mampu memberikan kepercayaan kembali terhadap publik (masyarakat).

\section{DAFTAR PUSTAKA}

Blau, Peter M., dalam George Ritzer \& Douglas J. Goodman, 2009, Teori Sosiologi, Dari Teori Sosiologi Klasik sampai Perkembangan Mutakhir Teori Sosiologi Post-Modern, Cetakan Ketiga, Yogyakarta: Penerbit Kreasi Wacana

Friedman, Lawrence M., 2011, Sistem Hukum Perspektif Ilmu Sosial (The Legal System A Social Science Perspective), Bandung: Nusamedia

Hafidz, Jawade, Sistem Pertanggungjawaban Perkara Korupsi Dalam Percepatan Penyelamatan Keuangan Negara, Jurnal Dinamika Hukum, Vol 11 Edisi Khusus, FH Unsoed Purwokerto, Februari 2011, hal 116

Indah, C. Maya, Refleksi sosial atas Kelemahan Hukum Modern : Suatu Diseminasi Hukum Tradisional dalam Citra Hukum Indonesia, Jurnal Masalah-Masalah Hukum, FH Universitas Diponegoro, Semarang, Vol 103 No. 37 , Tahun 2008, hal 164

Kusumatmadja, Mochtar, 1986, Pembangunan Hukum Dalam Kerangka Pembangunan Nasional, Cetakan Kedua, Bandung: Fakultas Hukum Universitas Padjajaran dan Bina Cipta

Mardin, Nurhayati, Makna Kepala Putusan Pengadilan : Keadilan Berdasarkan Ketuhanan yang Maha Esa (Tinjauan Rechtphilosophie), Jurnal Hukum Aktualita, Vol II No. 3, Desember-Maret 2007. FH Universitas Tadulako, hal 279 
Mustopadidjaja, AR., 2003, Reformasi Birokrasi Sebagai Syarat Pemberantasan KKN, Makalah Seminar Pembangunan Nasional VIII, Penegakan Hukum Dalam Era Pembangunan Berkelanjutan. BPHN Denpasar

Nusantara, Abdul Hakim Garuda, 1988, Politik Hukum Indonesia, Jakarta: Yayasan LBH Indonesia

Rahardjo, Satjipto, 1996, Ilmu Hukum, Bandung: PT. Citra Aditya Bakti

2003, Sisi Lain dari Hukum DI Indonesia, Jakarta: Penerbit Kompas

2007, Masalah Penegakan Hukum (Suatu Tinjauan Sosiologis), Bandung: CV. Sinar Baru

2009, Hukum Progresif Sebuah Sintesa Hukum Indonesia, Yogyakarta: Genta Publishing 2009, Hukum Progresif: Aksi, Bukan Teks dalam Memahami Hukum dari Konstruksi Sampai Dengan Implementasi, Jakarta: Rajawali Press

Rasjidi, Lili dan I.B Wyasa Putra, 2003, Hukum Sebagai Suatu Sistem, Bandung: Bandar Maju

Setiadi, Wicipto, 2012, Arti Penting Lembaga-lembaga Hukum di Indonesia dalam Merespon Perubahan Sosial, Dalam Jurnal Komisi Yudisial "Dialektika Pembaharuan Sistem Hukum Indonesia, Jakarta

Sibarani, Sinintha Y, Budaya Hukum Progresif Hakim Ad Hoc dalam Penegakan Hukum
Tipikor, dalam Proceeding Konsorsium Hukum Progresif 2013, di Hotel Patrajasa Semarang

Syarifudin, Amir, 2008, "Pengawasan Kinerja Peradilan Tipikor di Provinsi Sumatera Utara", pada Seminar yang diselenggarakan oleh Basis Demokrasi, Komisi Ombudsman Nasional Perwakilan Sumut dan NAD, di Grand Atares Hotel Medan

Sidharta, 2008, Posisi Pemikiran Teori Hukum Pembangunan dalam Konfigurasi Aliran Pemikiran Hukum (Sebuah Diagnosis Awal), Jakarta: Epistema Institute dan Huma

Soekanto, Soerjono, 1983, Faktorfaktor Yang Mempengaruhi Penegakan Hukum, Jakarta: Rajawali

Tim LBH Surabaya, (Masih) Berkuasanya Kekuasaan Kegelapan: Potret Penegakan Hukum dan HAM, Malang: InTrans Publishing, 2009, hal 1415

Warassih, Esmi, 2011, Pranata Hukum - Sebuah Telaah Sosiologis, Semarang : Badan Penerbit Universitas Diponegoro

Widodo, J. Pajar, Reformasi Sistem Peradilan Pidana Dalam Rangka Penanggulangan Mafia Peradilan, Jurnal Dinamika Hukum, vol. 12 No. 1, Januari 2012, hal 108

Winarta, Frans Hendra, 2012, Membangun Profesionalisme Aparat Penegak Hukum, Dalam Jurnal Komisi Yudisial "Dialektika Pembaharuan Sistem Hukum Indonesia, Jakarta 
Yunus, Nur Rohim, Menciptakan

Budaya Hukum Masyarakat

Indonesia dalam Dimensi

Hukum Progresif, dalam

Proceeding Konsorsium

Hukum Progresif 2013, di

Hotel Patrajasa Semarang,

Undang - Undang Dasar 1945

Undang - Undang Nomor 30 Tahun

2002 tentang Komisi

Pemberantasan Korupsi

Undang - Undang Nomor 46 Tahun

2009 Tentang Pengadilan

Tindak Pidana Korupsi.

Undang - Undang Nomor 48 Tahun 2009 Tentang Kekuasaan

Kehakiman

http://www.kpk.go.id/id/berita/siaran-

pers/1556-kasus-suap-hakim-

tipikor-semarang-kpk-tahan-

hakim-p

http://www.merdeka.com/peristiwa/teri

ma-suap-hakim-setyabudi-

divonis-12-tahun-penjara.html 